\title{
稻田及其毗邻杂草地寄生蜂群落结构与特征
}

\author{
徐敦明 ${ }^{12}$ 李志胜 $^{1}$ 刘雨芳 $^{3}$ 尤民生 $^{1}$ * \\ 1 (福建农林大学应用生态研究所, 福州 350002) \\ 2 (西北农林科技大学无公害农药研究服务中心, 杨凌 712100) \\ 3 (湖南科技大学生命科学学院, 湘潭 411201)
}

摘要: 通过在稻田及其毗邻杂草地的系统调查、采集和室内标本鉴定, 获知稻田中有 67 种寄生蜂, 隶属 16 科;毗邻 杂草地中有 96 种寄生蜂, 隶属 19 科。稻田生境中的寄生蜂物种数占稻田天敌总物种数的 $45.89 \%$ 杂草生境中的 寄生蜂物种数占杂草地天敌总物种数的 $46.60 \%$ 。对稻田及其毗邻杂草地寄生蜂群落的各种属性指标进行比较研 究 结果表明 :杂草地寄生蜂群落的丰富度、多样性、优势集中度指数均比稻田高, 而均匀性指数值比稻田低。对杂 草生境和稻田生境寄生蜂群落的优势种动态比较可知, 寄生蜂优势种在水稻的不同生育期是不相同的, 在稻田生 境中, 优势种稻風缨小蜂( Anagrus sp.) 出现在水稻生育前期和中后期, 等腹黑卵蜂 ( Telenomus dignus) 出现在水稻 生育后期 稻苞虫黑卵蜂 (Telenomus sp.) 在水稻生育前中期及后期出现。然而在杂草地中, 作为优势种, 稻䖝缨小 蜂出现在水稻生育前期和中期, 等腹黑卵蜂出现在水稻生育前中期和后期, 稻苞虫黑卵蜂在水稻整个生育期均有 出现。两种锤角细蜂 (Monelata sp. 1 和 Acropiesta sp. 2) 是稻田的重要优势种, 但不是杂草地的优势种; 相反, 稻蝽 小黑卵蜂( Telenomus gifuensis) 是杂草地的重要优势种, 但不是稻田的优势种。由此可见, 杂草地生境是稻田寄生蜂 的种库之一, 对稻田节肢动物群落的重建和种群保存有重要影响, 因而适当保留田埂杂草和稻田周围的杂草地, 减 少对天敌的损害, 提高天敌对害虫的自然控制作用, 是水稻害虫持续控制的途径之一。

关键词：稻田，杂草地，生境，寄生蜂，群落，多样性

中图分类号 : Q145.2 文献标识码 : A 文章编号 : 1005-0094(2004)03-0312-07

\section{Structure and characteristics of parasitoid communities in a rice field and adjacent weed habitat}

XU Dun-Ming ${ }^{1}{ }^{2}$, LI Zhi-Sheng ${ }^{1}$, LIU Yu-Fang ${ }^{3}$, YOU Min-Sheng ${ }^{1}$ *

1 Institute of Applied Ecology, Fujian Agriculture and Forestry University , Fuzhou 350002

2 Research and Development Center of Biorational Pesticides, Northwest Sci-Tech University of Agriculture and Forestry , Yangling 712100

3 School of Life Sciences, Hunan University of Science and Technology, Xiangtan 411201

\begin{abstract}
Based on outdoor surveys and suction device-based collections in a rice field as well as adjacent weed habitat from June to September 2001 and laboratory identifications of specimens obtained from the field investigations , 67 species of parasitoids were collected and identified in the rice field , and 96 in the weed habitat. The species number of parasitoids accounted for $45.9 \%$ of the total species number of natural enemies in the rice field, and $46.6 \%$ in the weed habitat. For a comparative study of community diversity , species richness $(S)$, Shannon-Wiener's diversity index $\left(H^{\prime}\right)$, Simpson's index of dominant centralization $(C)$ and Pielou's evenness $(E)$ were calculated. The results showed that the numerical values of $S, H^{\prime}$ and $C$ of the parasitoids in the weed habitat were higher than those in the rice field, and the value of $E$ was lower in the weed habitat. Temporal variation of dominant species was also different between the two habitats. In both habitats , Telenomus dignus and Anagrus sp. were dominant, but each habitat also had its unique dominant species , e. g. ,Monelata sp. 1 and Acropiesta sp. 2 were common in the rice field but not in weed habitat, while Telenomus gifuensis was only common in the weed habitat. The dominant species of the parasitoids tended to colonize the weed habitat in the seedling-transplanted
\end{abstract}


stage of rice , immigrate into the field in the growing stage of rice, and emigrate from the fields to live in the weed habitat again in the mature stage of rice. This clearly indicates that the weed habitat can serve as a" species pool" of natural enemies, which provides the enemies with opportunities for natural dispersal , host alternation and refuge-seeking when there is lack of suitable food or disturbances caused by cultivation in the rice field. This is favorable for ecologically-based integrated pest management in rice ecosystems.

Key words : rice field, weed habitat , parasitoid , community , diversity

稻田天敌的保护和利用一直被认为是水稻害虫 综合治理的有效措施( 尤民生等,1999)。寄生蜂是 水稻害虫最重要的寄生性天敌, 种类多, 数量大 ;已 报道的水稻害虫寄生蜂已达 345 种 (何俊华, 1992 ），对害虫的控制作用显著（Way \& Heong， 1994 ; Settle et al. 1996)。有研究表明, 与稻田邻近 的非稻田生境中咜存着丰富的天敌资源, 对稻田节 肢动物群落中天敌亚群落的物种丰富度、个体数量 及群落重建有着积极的作用( Stapley ,1975; Altieri， 1994 ; 毛润乾等, 1999 2001a 邱道寿等 2002; 刘雨 芳等 2002)。稻田周围的杂草地作为非稻田生境 的一个重要类型, 是稻田节肢动物群落的重要种库 之一(张古忍等,1997; 毛润乾等 ,2001b 张文庆等， 2002 )。但目前国内外对稻田杂草地生境的寄生蜂 群落结构和多样性的研究报道较少。本文着重比较 稻田及其毗邻杂草地寄生蜂群落的结构和多样性, 阐明毗邻杂草地对稻田寄生蜂的保护作用，以期为 水稻害虫的生态控制提供科学依据。

\section{1 材料与方法}

\section{1 调查地状况}

本项研究于 2001 年 6-9 月在福建省古田县湖 滨乡进行地理位置为 $118^{\circ} 32^{\prime}-119^{\circ} 23^{\prime} \mathrm{E}, 26^{\circ} 17^{\prime}$ $-26^{\circ} 52^{\prime} \mathrm{N}$, 属于亚热带季风气候, 年平均气温 $14-$ $20.2^{\circ} \mathrm{C}$, 年降雨量 $1400-2100 \mathrm{~mm}$ 。选择一块中稻 田和一块与中稻田相邻的杂草地作为调查地, 设两 个重复。稻田四周分别与杂草地、蔬菜地、再生稻田 和单季稻田邻接，地与地之间仅有田埂进行简单地 分割。每一稻田的面积约为 $1400 \mathrm{~m}^{2}$,杂草地的面 积约为 $1000 \mathrm{~m}^{2}$ 。杂草地主要杂草种类有:香附子 (Cyperus rotundus)、空心莲子草 (Alternanthera philoxeroides )、白茅 (Imperata cylindrical)、狗牙根 (Cynodon dactylon) 和游草 (Leersia hexandra) 等。稻田按 常规管理, 杂草地也没有采取任何的除草措施。

\section{2 调查方法}

稻田中采用吸虫器法 (刘雨芳等, 1999) 和目测 法进行五点对角线取样。目测法仅调查钻蛀性害 虫, 克服吸虫器法无法采集钻蛀性害虫的缺点。每 个样点抽吸 (和目测) 20 丛水稻 (20 丛约占 $1 \mathrm{~m}^{2}$ ), 水稻移栽 1 周时开始调查，以后每两周调查 1 次，直 到收割, 收割后调查 1 次, 共调查 9 次。杂草地采用 改装的吸虫器 (刘雨芳等, 1999) 取样, 每次调查随 机取 5 个样, 每个样方 $1 \mathrm{~m}^{2}$,与水稻田同步调查, 共 调查 9 次。样品用 $80 \%(\mathrm{~V} / \mathrm{V})$ 的酒精浸泡后, 带回 室内清理、分类鉴定。

\section{3 多度等级划分}

标本划分为 3 个等级: 优势种 (Berger-Parker 指 数 $I \geqslant 0.1)$ 、常见种 $(0.1>I>0.01)$ 和少见或偶见 种 $(I \leqslant 0.01)$ (庞雄飞, 尤民生, 1996)。

\section{4 分析方法和软件}

分析中采用如下几个特征值:物种数 $(S)$,个体 数量 $(A)$,Shannon-Wiener 多样性指数 $\left(H^{\prime}\right)$ ( Margalef ,1958)，Pielou 均匀度指数 (E) (Pielou ,1966)， Simpson 的优势集中度指数 $(C)$ (Simpson，1949)。 本文有关数据在 DPS (Data Processing System) 数据 处理系统 ( 唐起义 2002 ) 上处理完成。

\section{2 结果与分析}

2.1 稻田及其毗邻杂草地寄生蜂的群落结构组成

稻田生境中的寄生蜂物种数占稻田天敌物种总 数的 $45.89 \%$, 杂草生境中的寄生蜂物种数占杂草 地天敌物种总数的 $46.60 \%$ (图 1 ) ,比例均约占各 自天敌物种总数的一半, 可见寄生蜂具有相当重要 的地位。

在稻田及其毗邻杂草地共采集寄生蜂 3046 头, 其中稻田 716 头, 杂草地 2330 头。在稻田中鉴定出 67 种寄生蜂, 隶属于 16 科; 在毗邻杂草地中鉴定出 96 种寄生蜂, 隶属于 19 科。缘腹细蜂为优势类群， 在稻田和杂草地中个体数的比例分别为 $21.2 \%$ 和 $45.5 \%$,占各自生境寄生蜂总数的最大比例。就物 


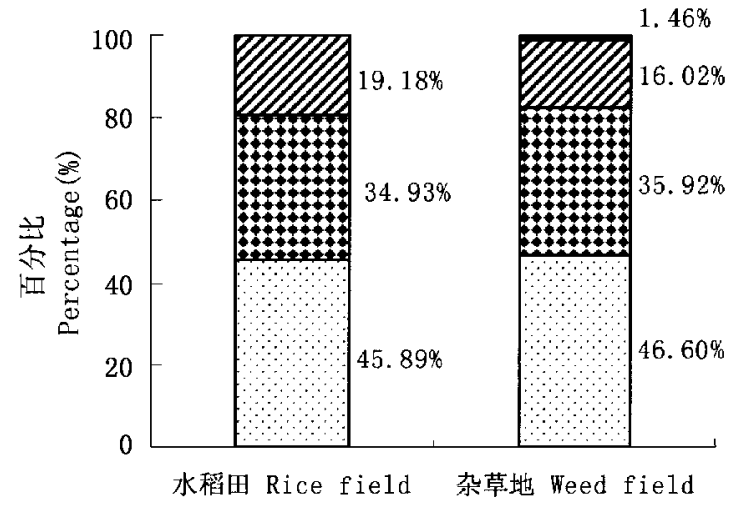

生境 Habitat

口捕食性昆虫 Predaceous insect

田蜘蛛 Spider

口寄生蜂 Parasitoid

口非寄生蜂寄生性天敌 0thers

图 1 不同生境各种天敌的物种数百分比

Fig. 1 Taxa percentage of natural enemies in different habitats
种数来看 稻田生境中赤眼蜂种类最丰富, 有 10 个 物种,占稻田寄生蜂总物种数的 $14.9 \%$, 其次是姬 蜂, 有 8 个物种, 占总数的 $11.9 \%$;杂草生境茧蜂物 种最丰富, 有 24 个物种, 占杂草地寄生蜂总物种数 的 $25 \%$ ，其次是蚜茧蜂，有 13 个物种，占总数的 $13.5 \%$ (表 1 )。

\section{2 不同生境寄生蜂群落的多样性比较}

稻田与杂草地寄生蜂群落各多样性指数存在显 著差异 (表 2)。杂草地寄生蜂的丰富度比稻田的 高, 多样性值也高于稻田。然而, 稻田寄生蜂群落的 均匀度值高于杂草地，优势集中度值低于杂草地的， 表明杂草地寄生蜂群落的均匀性比稻田差。

从图 2 可知, 水稻移栽后, 杂草地生境寄生蜂的 物种丰富度开始降低，在水稻分葍期 (6 月 22 日) 降 到最低值;而稻田寄生蜂的物种丰富度迅速提高。 分櫱期到拔节期 (6 月 22 日至 7 月 6 日)，两类生境 寄生蜂的物种丰富度稳定在一定水平上。在扬花期

表 1 古田稻田和杂草地寄生蜂物种数及个体数百分比

Table 1 Taxa and percentage of parasitoids in different habitats in Gutian , Fujian

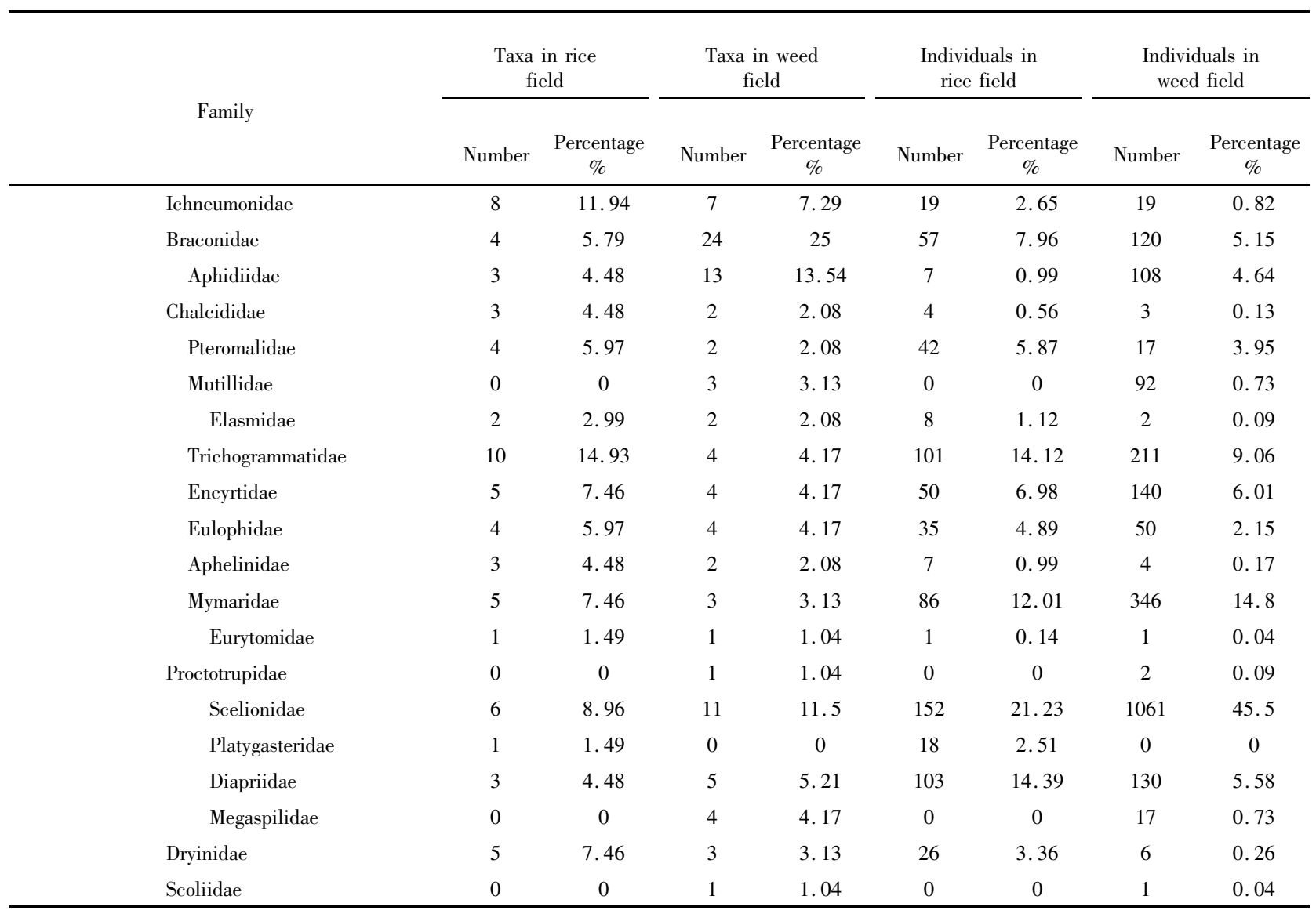


表 2 不同生境寄生蜂群落多样性比较

Table 2 Comparison of diversity of parasitoid communities in different habitats

\begin{tabular}{ccccc}
\hline $\begin{array}{c}\text { 生境 } \\
\text { Habitat }\end{array}$ & $\begin{array}{c}\text { 物种数 } \\
\text { No. of species }(S)\end{array}$ & $\begin{array}{c}\text { 多样性 } \\
\text { Shannon-Wiener } \\
\text { index }\left(H^{\prime}\right)\end{array}$ & $\begin{array}{c}\text { 均匀度 } \\
\text { Evenness }(E)\end{array}$ & $\begin{array}{c}\text { 优势集中度 } \\
\text { Simpson index }(C)\end{array}$ \\
\hline 水稻田 Rice field & 67 & $4.26771 \pm 0.32123^{*}$ & $0.86839 \pm 0.03412^{*}$ & $0.03367 \pm 0.00088^{*}$ \\
杂草地 Weed field & 96 & $4.63153 \pm 0.45678^{*}$ & $0.70335 \pm 0.06745^{*}$ & $0.06321 \pm 0.00231^{*}$ \\
\hline
\end{tabular}

*表示差异显著 Represents being significant $(P<0.05)$

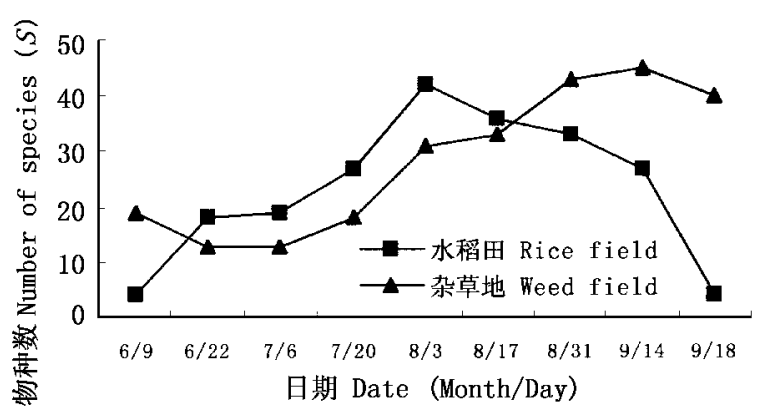

图 2 不同生境中寄生蜂群落的丰富度时间动态

Fig. 2 Temporal variation in taxa of parasites in different habitats

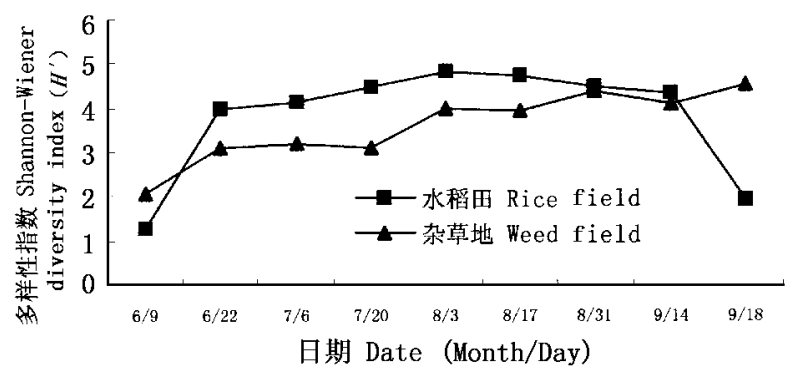

图 3 不同生境中寄生蜂群落的多样性时间动态

Fig. 3 Temporal variation in Shannon-Wiener index of parasites in different habitats

（8月 3 日）,稻田生境寄生蜂的物种丰富度升到最 高点。扬花期之后，稻田生境寄生蜂的物种丰富度 不断降低，杂草地生境寄生蜂的物种丰富度不断提 高, 可能是寄生蜂逐渐迁出稻田所致。

图 3 表明, 水稻移栽后, 寄生性天敌的物种多样 性在稻田生境先迅速上升到一较高点, 然后保持相 对稳定，至水稻收割前迅速下降，总体上呈钟状。同 期，在杂草生境寄生蜂群落多样性虽有小幅波动，但 总体上呈缓慢上升的趋势。群落的多样性是由物种 丰富度和均匀性共同决定的。水稻移栽后, 杂草生 境中寄生蜂群落物种数降低, 多样性反而升高。

水稻返青期 (6 月 9 日)至分菜期 (6 月 22 日)， 稻田和杂草地生境中的寄生蜂群落的均匀度快速增
大,优势集中度指数迅速减小,这是由于水稻移栽 后, 寄生蜂群落迅速重建趋于稳定所致。在分蒒期 (6月 22 日)之后，两类生境寄生性天敌群落的均匀

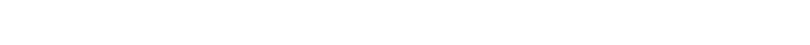
(Anagrus sp.) 的数量急剧增加影响。均匀度指数 在两类生境中的变化趋势基本类似。随水稻生育期 推进杂草生境寄生蜂群落的优势集中度指数呈下降 趋势 稻田生境呈现上升趋势, 但是均匀度指数和优 势集中度指数变化很小, 表明寄生蜂群落相当稳定 ( 图 4、图 5)。

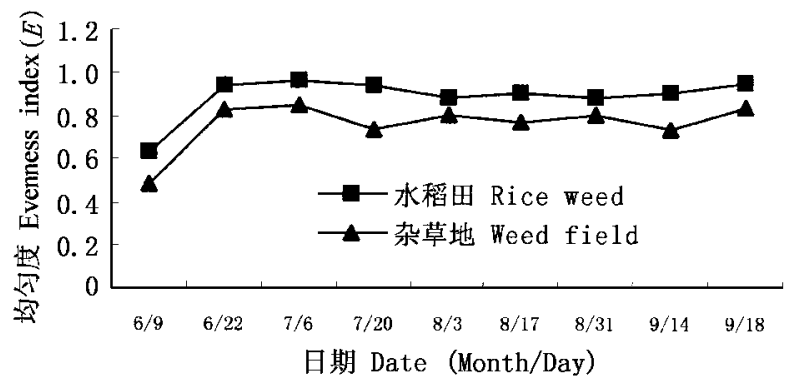

图 4 不同生境中寄生蜂群落的均匀度时间动态

Fig. 4 Temporal variation in Evenness index of parasites in different habitats

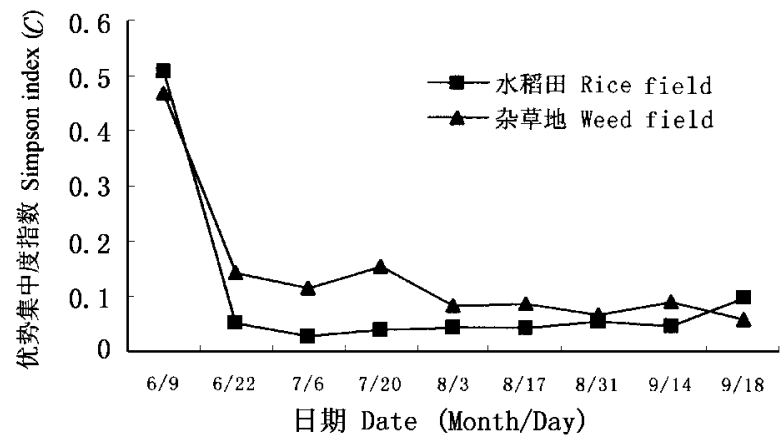

图 5 不同生境中寄生蜂群落的优势集中度时间动态

Fig. 5 Temporal variation in Simpson index of parasites in different habitats

\section{3 不同生境寄生蜂群落的优势种动态比较} 不同生境寄生蜂群落的优势种动态比较结果见 
表 3 不同生境寄生蜂群落优势种动态比较

Table 3 Comparison of temporal variation of dominant species from different habitats in Gutian , Fujian

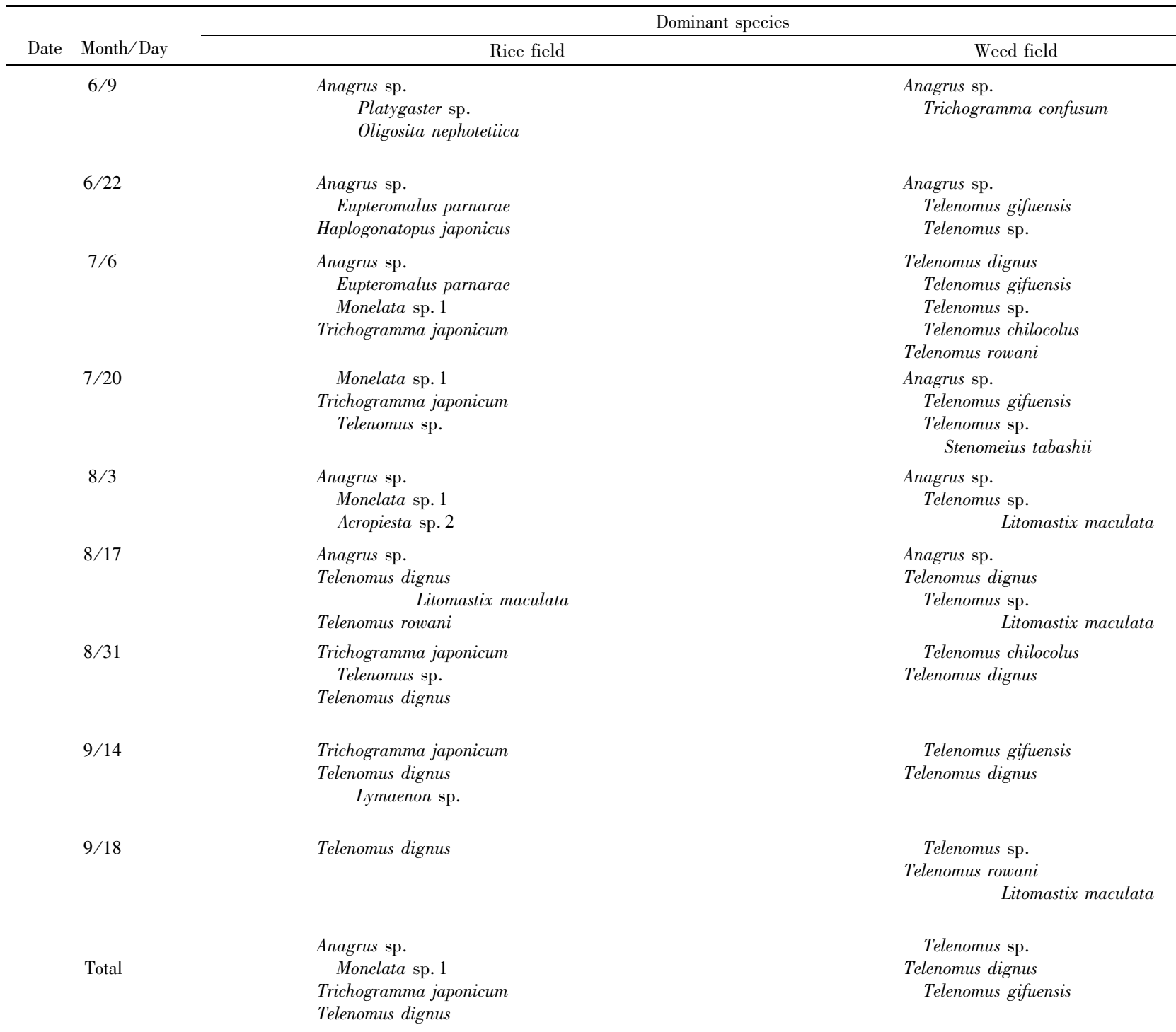

注 本表按 Berger-Parker 指数 $I \geqslant 0.1$ 来确定为优势种

Notes : Those species whose Berger-Parker index was over 0.1 were sorted into dominant species.

表 3。稻田寄生蜂群落优势种包括稻風缨小蜂 (Anagrus sp.) 、锤角细蜂一种( Monelata sp. 1)、稻蚯 赤眼蜂 (Trichogramma japonicum)、等腹黑卵蜂 ( Telenomus dignus) 杂草地寄生蜂群落优势种包括 稻苞虫黑卵蜂 ( Telenomus sp.) 、等腹黑卵蜂、稻蝽小 黑卵蜂 (Telenomus gifuensis)。锤角细蜂是稻田的重 要优势种, 但不是杂草地的优势种; 相反, 稻蝽小黑 卵蜂是杂草地的重要优势种, 但不是稻田的优势种。 稻田和杂草地寄生蜂优势种均包括等腹黑卵蜂。

稻田寄生蜂优势种在水稻的不同生育期是不相 同的 稻風缨小蜂出现在水稻生育前期和中后期, 锤
角细蜂出现在水稻生育中期, 等腹黑卵蜂出现在水 稻生育后期 稻螟赤眼蜂和稻苞虫黑卵蜂在水稻生 育前期、中期及后期都有出现。然而在杂草地中 稻 風缨小蜂出现在水稻生育前期和中期，稻蝽小黑卵 蜂出现在水稻生育前期和后期, 稻苍虫黑卵蜂在水 稻整个生育期均有出现, 等腹黑卵蜂出现在水稻生 育前、中期和后期。两类生境中优势种动态是不同 的，水稻移栽后优势种等腹黑卵蜂和稻苍虫黑卵蜂 在杂草地比在稻田出现早, 可推测稻田中的黑卵蜂 是从杂草地迁入; 水稻接近收割时银纹夜蛾斑多胚 跳小蜂 (Litomastix maculata) 不再是稻田的优势种， 
而成为杂草地的优势种, 这有可能是跳小蜂从稻田 迁出而造成。

\section{3 小结与讨论}

寄生蜂是水稻害虫最重要的寄生性天敌, 具有 非常重要的作用和地位。通过田间系统调查、采集 和室内标本鉴定, 初步明确了福建省古田县中稻稻 区及毗邻杂草地寄生蜂的种类 (李志胜等 2002 ; 徐 敦明等 2003)。稻田中有 67 种寄生蜂 , 杂草地中有 96 种寄生蜂 稻田生境和杂草地生境中的寄生蜂物 种数分别占各自天敌物种总数的 $45.89 \%$ 和 $46.60 \%$ 表明两类生境中咜存着丰富的寄生蜂资 源。在两类生境中, 寄生蜂的数量也是非常大的, 共 采集到 3046 号标本。

群落的多样性在一定程度上反映了群落的稳定 性。两类生境寄生蜂群落的多样性比较研究表明, 杂草地寄生蜂群落的丰富度比稻田高, 多样性值也 高于稻田, 这说明杂草地生境寄生蜂资源相当丰富。 然而, 稻田寄生蜂群落的均匀度值高于杂草地, 而优 势集中度值低于杂草地, 可见杂草地寄生蜂群落的 均匀性比稻田差, 这也许是杂草生境中某一物种数 量极大所致。可见，多样性高不一定均匀性好，群落 多样性应包括群落所含的物种数多寡和群落中各个 种的相对多度。因而, 评判一个群落的多样性和稳 定性, 应对该群落的物种丰富度、个体数及各种多样 性指标进行综合分析。

稻田生态系统是一个不稳定的短期作物系统, 生活在其中的节肢动物随水稻的移栽、生长和收割 而不断经历着群落的重建、发展和瓦解的过程 (张 文庆等 2002)。在此过程中, 非稻田生境对稻田节 肢动物群落的重建和种群保存有重要影响。本研究 中，从寄生蜂群落特征指标时间动态来看 稻田和杂 草地之间的寄生蜂存在物种交流。水稻移栽后寄生 蜂逐渐迁入稻田，水稻成熟后寄生蜂又逐渐迁出稻 田 进入杂草生境。通过对杂草生境和稻田生境寄 生蜂群落的优势种动态比较可知, 两类生境中优势 种时间动态是不同的。水稻生长前期, 同种优势种 杂草地比稻田出现早; 当水稻接近收获时, 杂草生境 中调查到了出现在水稻生长中期时水稻生境中的优 势种。这种变化趋势进一步证明杂草地生境是稻田 寄生蜂的种库之一。因而，在生产上简单地将稻田 周围的杂草视为 害虫库” 而加以清除的做法并不
可取, 适当保留田埂杂草和稻田周围的杂草地, 减少 对天敌的损害，提高天敌对害虫的自然控制作用，是 水稻害虫持续控制的途径之一。

致谢 : 福建农林大学林乃铨教授、黄建教授、吴梅香 博士、宋东宝博士、徐梅博士、胡红英博士等协助鉴 定部分昆虫标本。9 8 级本科生黄顶成、蒋文超参加 部分田间调查工作。在此，一并表示衷心感谢！

\section{参考文献}

Altieri, M. A. 1994. Biodiversity and Pest Management in Agroecosystems. Food Products Press, Canada, $1-34$.

He, J. H. (何俊华). 1992. List of Natural Enemies of Insect Pests on Rice in China (中国水稻害虫天敌名录). Science Press, Beijing, 244. (in Chinese)

Li, Z. S. (李志胜), Xu, D. M. (徐敦明), Zhuang, J. X. ( 庄家 祥), Wei，G. R. (魏观如), Liu，Y.F. (刘雨芳) and You, M. S. ( 尤民生) . 2002. Investigation on parasitoids in the weed habitat adjacent to rice fields. Wuyi Science (武夷科 学), 18: 19 -23. (in Chinese with English abstract)

Liu，Y.F. (刘雨芳)，Gu，D. X. (古德祥) and Zhang, G. R. (张古忍). 2002. An investigation of species of predatory arthropods in paddy ecosystems. Natural Enemies of Insects (昆虫天敌), 24: 145 - 153. (in Chinese with English abstract)

Liu, Y. F. (刘雨芳), Zhang, G. R. (张古忍) and Gu, D. X. (古德祥). 1999. Studies on arthropod community in rice fields through the modified insect sucker. Plant Protection (植物保护)，25 (6): 39 - 40. (in Chinese with English abstract)

Mao, R. Q. (毛润乾)，Gu，D.X. (古德祥)，Zhang，G. R. (张 古忍) and Zhang, W. Q. (张文庆). 2001a. Comparison studies on rice hopper egg-parasitoid communities between IPM and non-IPM ecosystems. Chinese Journal of Ecology (生态学杂志), 20 (3) : 17 - 20. (in Chinese with English abstract)

Mao, R. Q. (毛润乾), Gu， D. X. (古德祥) and Zhang, G. R. (张古忍) . 2001b. Dynamics of brown planthopper egg-parasitoid community in non-rice habitats. Acta Ecologica Sini$c a$ (生态学报), 21: 942 -947. (in Chinese with English abstract)

Mao，R. Q. (毛润乾), Gu，D. X. (古德祥), Zhang, W. Q. (张 文庆) and Zhang, G. R. (张古忍). 1999. Egg parasitoids of brown planthopper Nilaparvata lugens. Natural Enemies of Insects (昆虫天敌), 21: $45-47$. (in Chinese with English abstract)

Margalef, R. 1958. Information theory in ecology. General Sys- 
tems, 3: $36-71$.

Pang，X. F. (庞雄飞) and You，M. S. ( 尤民生)．1996. Insect Community Ecology (昆虫群落生态学). China Agriculture Press, Beijing, 77 - 103. (in Chinese)

Pielou, E. C. 1966. The measurement of diversity in different types of biological collections. Journal of Theoretical Biolo$g y$, 13: $131-144$.

Qiu, D. S. (邱道寿), Gu, D. X. (古德祥) and Zhang, G. R. (张古忍). 2002. Reestablishment of dominant species populations of spider community in paddy fields. Acta Arachnologica Sinica (蛛形学报), 9: 23 - 28. (in Chinese with English abstract)

Settle, W. H., Ariawan, H. and Astuti, E. T. 1996. Managing tropical rice pests through conservation of generalist natural enemy and alternative prey. Ecology, 77: 1975 1988.

Simpson, E. H. 1949. Measurement of diversity. Nature, 163: 688.

Stapley, J. H. 1975. The problem of the rice brown planthopper, Nilaparvata lugens on rice in the Solomon islands. Entomology Newsletter, 4: $15-16$.

Tang, Q. Y. (唐起义). 2002. DPS (Data Processing System) (数据处理系统). Zhejiang University, Hangzhou. (in Chinese)

Way, M. J. and Heong, K. 1994. The role of ecosystem biodiversity in the dynamics and management of insect pest of tropical irrigated rice: a review. Bulletin of Entomological Research, 84: 567 - 587 .

Xu, D. M. (徐敦明), Li, Z. S. (李志胜), Liu, Y. F. (刘雨 芳), Zhuang, J. X. (庄家祥), Wei, G. R. (魏观如) and You，M. S. ( 尤民生). 2003. Investigation on arthropod species in paddy fields. Journal of Northwest Sci-Tech University of Agriculture and Forestry (西北农林科技大学学 报), 31 (5): 101 - 105. (in Chinese with English abstract)

You, M. S. ( 尤民生), Wang, H. C. (王海川) and Yang, G. (杨广). 1999. A study on the sustainable control of agriculture insect pests. Journal of Fujian Agriculture University (福建农业大学学报), 28: $434-440$. (in Chinese with English abstract)

Zhang, G. R. (张古忍), Gu，D. X. (古德祥) and Zhang, W. Q. (张文庆). 1997. Species pools of predatory arthropod communities and community rebuilding in paddy fields. Chinese Journal of Biological Control (中国生物防治), 13 (2) : 65 - 68. (in Chinese with English abstract)

Zhang, W. Q. (张文庆), Gu, D. X. (古德祥) and Zhang, G. R. (张古忍). 2002. The reestablishment of the arthropod community in short-term crop fields. II. Analysis and manipulation of the community reestablishment. Acta Ecologica Sinica (生态学报), 21: 1020 - 1024. (in Chinese with English abstract) 